\title{
Do monkeys tell themselves? Passions and doubts of ethology
}

\section{Zaietta ${ }^{1}$}

${ }^{1} \mathrm{PhD}$ candidate in Philosophy. Consortium Philosophy North West Italy [FINO] | Université Paris 1 PanthéonSorbonne

submitted: Mar 22, 2017, accepted: Apr 14, 2017, EPub Ahead of Print: Apr 20, 2017, published: May 1, 2017 Conflict of interest: None

DOI: 10.24019/jtavr.13 - Corresponding author: Dr. Lucia Zaietta, luciazaietta@gmail.com

(C) 2016 Fondazione Vasculab impresa sociale ONLUS. All rights reserved.

What is a primatologist? A zoologist first and foremost? An anthropologist interested in early man? A socio-biologist following selfish genes? A psychologist?

Bruno Latour

Keywords epistemology, ethology, animal-human relationship, anthropomorphism, science's narratives

In the '70, the well-known psychologist Gordon Gallup proposed a test to a chimpanzee called Sarah. Sarah was not an 'ordinary' chimpanzee, because she had learned to communicate through sign language. Gallup gave her some pictures representing human beings (men and women known by Sarah) and others chimpanzees Sarah lived with. Sarah was asked to separate humans from animals. She did it without hesitation: on the one side, she put all her animal companions and, on the other side, she put all the humans, including herself (Picq et al. 2003 ${ }^{1}$ ). Sarah seemed to consider herself as a human. Maybe, it's us that made her human.

To this day, the boundaries between human and animal beings have never been so nuanced. Above all, when it comes to primates. Primatology has produced essential results in recognizing incredible abilities to chimpanzees, macaques, gorillas and so on: intelligence, sociality, cooperation and a sort of primordial technology are already present in primates' behaviour. Thanks to primatology, we got an extensive knowledge of the common ground between primates and us. And yet, there is another way to think about the boundaries between what we call 'human' and 'animal'. This other manner lies in the boundary itself, and it concerns the way we, humans, look at animals: "what was my impression looking into the eyes a monkey for the first time? ". The same question goes for scientific gaze: which kind of look characterizes science? Is it an objective and neutral gaze? And what about primatology?

This kind of questions are at the heart of Augusto Vitale's book: Le scimmie si raccontano? Passioni e dubbi dell'etologia $^{2}$ (Do monkeys tell themselves? Passions and doubts of ethology) (Figure 1). For one thing, this book arises from different needs: first of all, the need to stop and consider what the encounter with an animal's gaze can tell us and, at the same time, what our human gaze can reveal about animals.

It's a matter of contamination: Vitale's book concerns precisely the grey area of intersection and overlapping between the stories of the one who looks at a behaviour and the stories of the one who is the lead of that behaviour (Vitale 2016, p.12).

This book has also to do with questions: with the essence of the question of life science and with the right question of ethology (See for example Despret $2014^{3}$ ). Science, and ethology most of all, is based on questions and questions are always contextualized and theory-based. The theory at the heart of the scientific question concerns a specific and scientific vision as much as the social, cultural and personal context. As we will see, science inaugurates new paradigms just when it changes questions. 


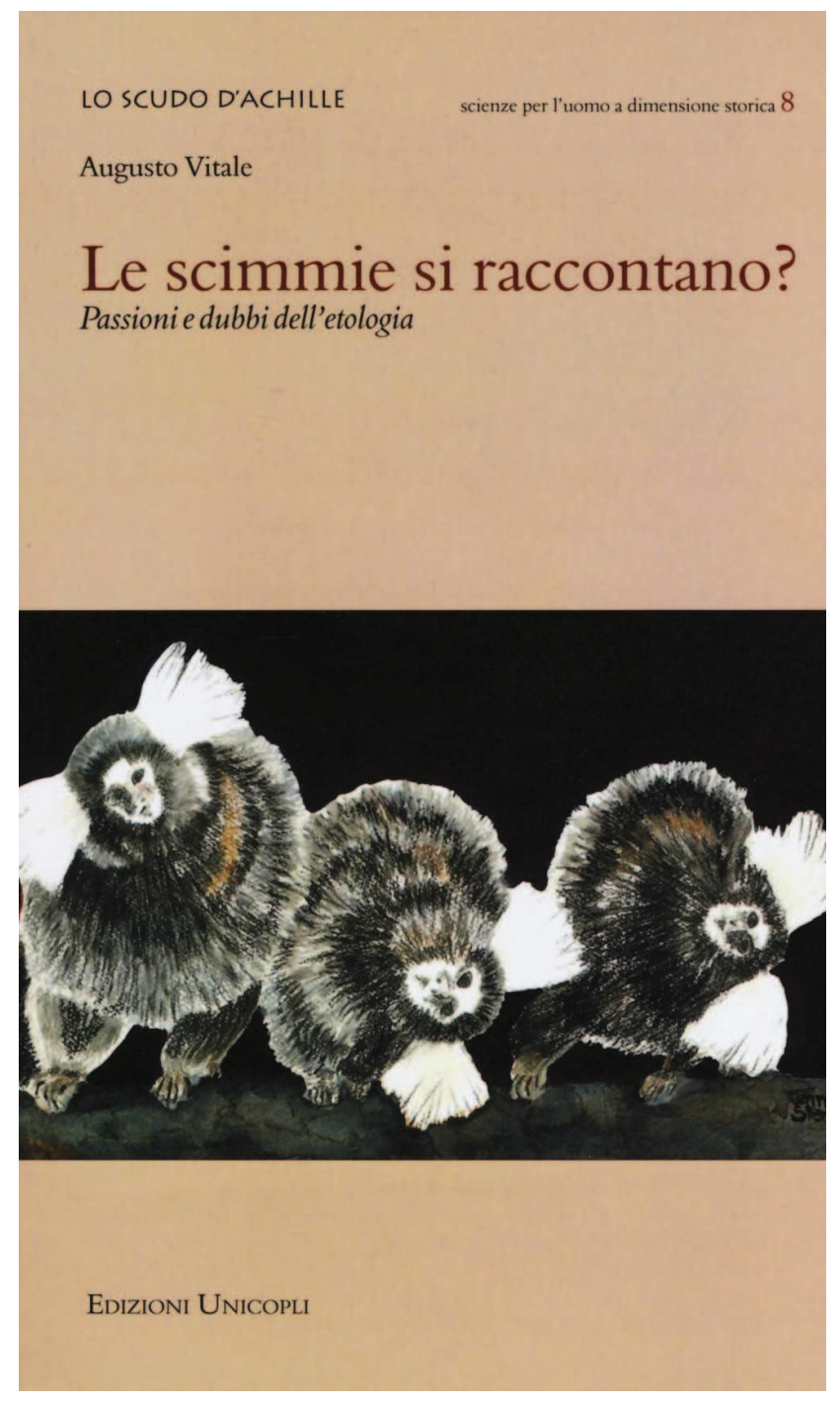

Figure 1 - Augusto Vitali. Le scimmie si raccontano? Passioni e dubbi dell'etologia.

Furthermore, Vitale's book is a novel. And it is in a very peculiar way: it is a sort of meta-novel. Through the history of ethology and primatology, as much as through his personal experience as researcher, the author tells us the narrative nature of science, or better it tells the way science tells nature. As well as the way monkeys tell themselves.

The overlapping of all these levels should not confuse: the main thrust of Vitale's book is very clear and it concerns the classical problem of the relationship between subjectivity and objectivity in science. That is, more precisely, the problem of anthropomorphism in ethology or, more radically, if anthropomorphism is a problem or not for ethology. In a nutshell, we can define 'anthropomorphism' as the tendency to interpret the physical and animal world in analogy to our inner experience. As humans, we have a specific way to live, to perceive and to understand the world, and the scientific inquiry is a part of that. For this reason, anthropomorphism is strictly connected to science and to the role of human subjectivity in it. This is most apparent in the field of ethology, that is the study of the behaviour of animal beings. Is it truly possible a purely objective ethology? What is the role of the scientist's subjectivity? Can we assume an anthropomorphic principle as a heuristic and useful research tool?

Le scimmie si raccontano is divided in four chapters, that represent four different approaches to the issue. The first chapter is a quick but exhaustive look-back over some highlights of the history of ethology in the light of the relationship between animal and human beings. It immediately emerges the anthropomorphic 'problem': why ethological research prefers certain animals? What about the criteria on which this preference is based? Is ethology immune to anthropomorphism? Is it legitimate to consider the animal as subject, by adopting qualitative criteria? Is it legitimate to consider the animal as equipped with personality, temperament and, in a word, singularity? The same questions characterise the second chapter, that is focused on primatology.

Here, Vitale meditates on scientific models used in primatology and, specifically, on the way in which models change according to the questions preceding and the results following an ethological study. By comparing the most exciting and influential researches on sociality in primates' worlds (De Wall, Schino, Aureli, Tomaselli and Visalberghi, to name a few), what emerges is a wide variety of ethological narratives: these studies have profoundly changed our vision on primates, as much as the way we tell them. Behind each research and each result, in fact, we find the world of the observers, a world made of questions, motives and passions. The third chapter of Vitale's book is precisely devoted to this 'scientific backstage' (Vitale 2016, p. 76) of the history of primatology.

Actually, there is no one primatology, but different primatologies, each with their own specificity. Vitale wants to bring out the reasons why we have come to study certain aspects of primates' behaviour: has primatology always studied sociality and altruism? Has it always asked the same questions? And what about the impact of prominent scientist on primates' science? In this chapter, the narratives succeed one another: "there is no one history of primatology, but many histories for many primatologies" (Ibidem, p. 79). Haraway's Primate visions (Haraway 1989 ${ }^{4}$ ) and Strum and Fedigan's Primate Encounters are the reference books (Strum and Fedigan $2000^{5}$ ). Two examples are given to illustrate how love, power, and science intertwine in the constructions of nature in the late twentieth century (Haraway 1989).

The first example shows the differences between Japanese primatology and the western one (Vitale, p. 79-94). Vitale tells us the great adventure of Imanishi, Itani and Nishida (to name a few), emphasising the specificity of 
Japanese primatology. Governed and subjective at the same time, Japanese primatology is not familiar with the dualism human/non-human and neither with either-or fallacy. This enables a specific vision on primates' capacities, that is captured in all its significance by the notion of kyokan (Kawai $1969^{6}$ ).

This word means literally "feel-one" and it indicates the sympathetic and, finally, anthropomorphic method adopted by Kawai (and to a lesser extent by Japanese primatology). This notion brings out an interesting revision about the classical western distance between subjectivity and objectivity. In the words of Kawai, "that by positively entering the group, by making contact at some level, objectivity can be established. It is on this basis that the experimental method can be introduced into natural behaviour study and which makes scientific analysis possible. [...] It is probably permissible to describe the method of the Primates Research Group as 'the new subjectivity"' (Kawai, in Asquith 1981, p. $346^{7}$. See also Haraway 1989).

The second example concerns the role and the revolution of women's gaze in primatology. The references are clearly Jane Goodall, Diane Fossey and Biruté Galdikas, as well as Jeanne Altman, Shirley Strum, Linda Fedigan and Thelma Rowell. The role of these women has been crucial in the deconstruction of the androcentrism that characterised primatology prior to the 1970 's. As Vitale underlines (Vitale 2016, p. 96), it's not about a gender battle, it's about the contribution a minority can make with regard to a vision monopolized by a majority (Tang-Martinez $2000^{8}$ ).

These two examples, Vitale explains in details, highlight a crucial aspect of primatology (and life science in general): on the one hand, a primate behaves in the same way and he'll keep on; on the other hand, the way we look at this behaviour changes according to the geographic, social and cultural context. In a word, according to the worldview of the observer (Vitale 2016, p. 97). This brings us to the four chapter, in which Vitale collects his conclusions, his right questions. Science tells nature, it tells what happens "out there" (Hinde 20009). Is the narrative character of life science a limit for the rigour that is requested to? Vitale rightly stresses the separation between data and interpretations.

The latter is not a neutral and independent process: it arises from historical, cultural and personal circumstances and it follows predictions and hypotheses. In the words of Latour, "Facts are circulating entities" (Latour, 2000 ${ }^{10}$ ). It is important to underline that is not a distortion from the outside. Life sciences, and primatology most of all, have to do with narratives, metaphors and feelings: they have to do with human language.
It was Adam who named animals, after all. Augusto Vitale offers a well-balanced point of view on the intertwining of stories and narratives characterising life sciences, and offers and interesting approach to accept and include a good anthropomorphism in ethology. A wide debate is at work: starting from Lorenz to Jay Gould and Bekoff. Maybe, it is precisely by recognising a certain amount of anthropomorphism that an unjustifiable anthropocentrism can be avoided. Even if they are frequently lumped together, anthropomorphism and anthropocentrism are not at all synonymous.

This is the opinion of Viveiros de Castro, for example: the human projection is not necessarily a symptom of anthropocentrism. As Viveiros de Castro shows through the study of Amazonian perspectivism, anthropomorphism and anthropocentrism refer to cosmological attitudes that are radically opposed. On the one hand, anthropomorphism relativizes the human exceptionality, that is the main feature of anthropocentrism, by attributing humanity to the other non-humans. On the other hand, anthropocentrism radicalises human boundaries, elevating human to the status of a special and exceptional being (Viveiros de Castro $2015^{11}$ ).

Then again, the dichotomy anthropomorphism VS science is counterproductive, especially when it comes to ethology and to the study of primates' behaviours. It is a question of language and of its limits: the way human beings describe behaviour is limited by the language they use, namely the human language. When dealing with animals' behaviours, feelings or emotions, the anthropomorphic language can make other animals' worlds accessible to humans. As Bekoff claims: "Using anthropomorphic language does not have to discount the animal's point of view. Anthropomorphism allows other animals' behavior and emotions to be accessible to us. Thus, I maintain that we can be biocentrically anthropomorphic and do rigorous science" (Bekoff 2000 ${ }^{12}$ ).

An acknowledgement of a multifactorial background, constituted by stories, visions, questions and bias, does not entail a confusion between subjectivity and objectivity and it does not menace the scientific value, which is the increase of knowledge. Maybe - and it is Vitale's argument - this kind of acknowledgement improves the scientific methodology, at least in respect of primatology. To a certain extent, the human and personal background of the scientist is unavoidable and it should be taken into account. Or even, it should be used as a heuristic strategy.

In this regard, the study of Thelma Rowell concerning the behaviour of sheep is inspiring in this regard. The peculiarity of this study relates to the original - and revolutionary - point of view assumed by Rowell: she has studied sheep asking different questions, or better by treating them as chimpanzees. As reported by Latour (and 
Vitale 2016, p. 123), Rowell wanted to give her sheep "the opportunity to behave like chimps, not that I believe that they would be like chimps, but because I am sure that if you take sheep for boring sheep by opposition to intelligent chimps they would not have a chance". In this context, Latour underlines the subtle but crucial difference between a bias and an opportunity. As he affirms, "A whole new philosophy of scientific practice resides in this extraordinary statement: 'to give the opportunity to behave' is not the same thing as 'imposing a bias onto' animals that cannot say a thing" (Latour 2000). Precisely by a deliberate decision, precisely by an artificial and anthropomorphic collage between 'charismatic' chimpanzees and 'boring'

\section{References}

1) Picq P, Michel S, Jean-Didier V. Qu'est-ce que l'humain?. Paris: Le Pommier;2003.

2) Vitale A. Le scimmie si raccontano? Passioni e dubbi dell'etologia. [Do monkeys tell themselves? Passions and doubts of ethology] Milano: Unicopli. Lo scudo di Achille; 2016. ISBN 8840019006, 9788840019000 .

3) Despret V. Que diraient les animaux, si on leur posait les bonnes questions ? Paris: La Découverte;2014.

4) Haraway D. Primate Visions: Gender, Race, and Nature in the World of Modern Science. New York - London: Routledge;1989.

5) Strum SC, Fedigan LM. Editors. Primate Encounters: Models of Science, Gender, and Society. Chicago: The University Chicago Press;2000.

6) Kawai M. Life of Japanese Monkeys. Tokyo: Kawade Shyoho Shinshya;1969.

7) Asquith PJ. Some Aspects of Anthropomorphism in the Terminology and Philosophy Underlying Western and Japanese Studies of the Social Behaviour of Non-human Primates. Oxford: Oxford University; 1981. sheep, Thelma Rowell has been able to reveal what sheep really are (Latour 2000).

Augusto Vitale's book is a useful and compelling instrument to call into question what we think ethology is and what ethology really is. Namely, an intertwining of different stories developing along different narrative levels: the narrative of ethology and ethologist, the evolutionary narrative, the narrative of the specific population of a specific study, the narrative of the social relationships into a group, the narrative of the individual member. Finally, the narrative of the observer, of course. These are the layers of the single and exciting history of ethology and these are the steps Vitale masterfully retraces.

8) Tang Martinez Z. Paradigms and Primates: Bateman's Principle, Passive Females, and Perspectives from Other Taxa. In: Strum SC, Fedigan LM, editors. Primate Encounters: Models of Science, Gender, and Society. Chicago: The University Chicago Press;2000, p. 261-274.

9) Hinde R. Some Reflections on Primatology at Cambridge and the Science Studies Debate. In: Strum SC, Fedigan LM, editors. Primate Encounters: Models of Science, Gender, and Society. Chicago: The University Chicago Press;2000, p. 104-115.

10) Latour B. A Well-articulated Primatology: Reflection of a Fellow Traveller. In: Strum SC, Fedigan LM, editors. Primate Encounters: Models of Science, Gender, and Society. Chicago: The University Chicago Press;2000, p. 358-381.

11) Viveiros de Castro E. Cosmological Perspectivism in Amazonia and Elsewhere. In: Viveiros de Castro E. editor. The Relative Native. Essays on Indigenous Conceptual Worlds. Chicago (IL): HAU Books;2015, p. 191-294.

12) Bekoff M. Animal Emotions: Exploring Passionate Natures. BioScience. 2000;50:861-70. 